\title{
Sociological Implications on Safety of Journalism as a Profession in Nigeria
}

\section{| Ogunmefun Folorunsho Muyideen ${ }^{1}$ | Raheem Olalekan Akeem ${ }^{2}$ |}

\author{
${ }^{1}$ Department of Criminology and \\ Security Studies, Chrisland \\ University, Owode, Abeokuta \\ Ogun State \\ ${ }^{2}$ Departement of Sociology, \\ Univerisity of Ibadan
}

${ }^{1}$ folorunshoogunmefun@gmail.com 2rolalekan14@gmail.com

\begin{abstract}
All over the world, Journalists are known as the fourth realm of the Estate charged with the responsibility of disseminating information to the societal members. Despite the contribution of the noble profession towards nation building, large number of journalist in the past and recent time in Nigeria faces series of challenges ranging from kidnapping, assault, harassment, torture, arbitrary detention, murder, imprisoned at the virtue of saving the nation. The gravity and magnitude of the prevalence insecurity in the profession has gotten to a state of psychological trauma and lost of interest for the profession. Several publications were reviewed; Anomie (Robert Merton) and Situational Crime Prevention (Ronald Clarke) theories were adopted. Qualitative method and purposive sampling technique was adopted in conducting in-depth interviews among 10 public members and 25 journalists from 4 media print Organisations, 3 radio stations and 2 television stations in Nigeria, In Nigeria journalist are faced with numerous insecurity issues and there is an urgent need to readdress the issues to save the nation from retrogressive development. Several recommendations are stated to safe the profession (a) the struggle for the survival of the profession should not be left alone to either the Government or the journalists it should be collectively addressed by all, More so, proactive methods, deterrence measures target hardening, access and facilitators control needs to be in placed to tackle the menace KEYWORDS
\end{abstract}

Sociological; safety; journalism; profession; development.

\section{INTRODUCTION}

The construction of reality in the developing nations seems to be relegated to the background and there is an urgent need to readdress the situation. In Nigeria, the problem of unemployment in the country has led to insecurity of almost all professions in the country. The situation has gathered its momentum up to a level that leaders in the developing nations cannot really clarify the differences between warfare and welfare nations. Soyombo and Oyekanmi (2015) and Ninalowo (2010) aver that the constitutional obligation of the State and the security apparatus is to provide ameliorative incentives for the improvement of human living conditions of the entire citizens. More so, in the other token it is also the obligations of the citizens to pay tax and obey national call of the State in order to achieved semblance of orderliness

In every human society the significant role of the profession of journalism cannot be overemphasized because they are considered as the fourth realm of the Estate, bedrock, prime mover, cornerstone and the bridge that linked and disseminate governmental enacted policies with the society members. Evidence gathered from several publications indicated that most of the media houses and the journalists have deviated from the moral ethics of the 
profession. They (Journalists) are working in favour of the bourgeoisie and the State government that established the organization for a particular purpose. For example, Dare (2010) explains that most bourgeoisie or politicians that established media organization uses their absolute right to dictate what goes into the radio stations and pages of the newspaper without looking at the ethics that guides the operation of the profession. In addition Dare further argued that most of the Nigerian Government and private owned media organizations are set to protect the interest of the owners of the organization, which may lead to continuous violation of the empirical code of ethics of the journalist as a profession in Nigeria.

In Nigeria the ethics guiding mode of operation of the journalists is set on the principle of transparency, objectivity, neutrality and accountability. But in recent times in Nigeria, the ethics governing code of conduct of the profession (Journalism) is eroded because of vested interest of the owners of the media houses at the detriment of the general interest of the public members. The ethics guiding the mode of operation of the media houses is of great branch of philosophy that involves systematizing, defending and recommending concepts of right and wrong conduct, often addressing disputes of moral mixture (Pate, 2013). In Nigeria today, the profession known as journalism is subjected to different interpretations. To some, the era of over relying on Government ownership of the media houses has gotten to a state where individuals are also licensed to operate media organization in Nigeria. For example, scholars are of the opinion that application of moral ethics in any profession will increases the act of choosing among good, ugly and bad options that individual faces in the society concerning role and significance of the profession of disseminating constructive information to the populace. But the societal perception of the profession is more destructive because media information is used to mislead innocent people in the country (Black and Roberts, (2011) Watds (2013) and Thornton (2012)

In Nigeria, societal value is an important and lasting beliefs or ideas shared by the members of a culture about what is good or bad and desirable or undesirable. The value associated with the role Nigerians places on the profession (Journalism) will determine an individual behaviour and attitude and serve as broad guidelines in all situations on what is right and wrong and about how journalists should behave in the course of their profession. In an country in the world, journalist are expected to refrain from publishing inaccurate and misleading information. However, when such inaccurate information are disseminated or published, adequate and urgent correction must be made in the society. According to Brown (2011) journalists are expected to sort for adequate and right procedure for cardinal rule of practice. In addition to their constitutional duties, journalists are expected to strive in order to separate facts from conjecture and comment. In addition, when the public members are misled based on the inadequate information disseminated or published by the journalists in any dimension it will affect the entire society leading to civil unrest, psychological trauma, retrogressive economic development, lack of trust in the activities of the government and the journalists and crisis of legitimacy in the country

Nigerian Journalists are today in deep crisis of credibility as a result of individual, organizational, environmental and societal challenges faced by the experts in the ptofession. More so,, cherished norms and values of the profession have been abused, violated and debased. Therefore, a rethink and return to the traditional values of truthfulness, neutrality and impartially may return the lost glory. For the profession to earn respect, recognition, and credibility in the mode of operation, truthfulness, neutrality and objectivity should become the most valuable things they will all time addressed. As a profession, the code of conduct should be revisited and reworked to state clearly the prerequisite qualifications necessary or required of a profession especially as it relates to the contemporary demands of the profession. 


\section{Research Questions}

1) What are the predisposing factors that lead to insecurity in the Journalism as a profession in Nigeria?

2) What are the societal interpretations of the profession in Nigeria?

3) Are there any forms of strategic security measures put in place by the State security apparatus to secure of the profession?

4) Are there any hope for the survival of the profession

\section{Theoretical Framework}

The beauty of academic research work is anchored on the use of theoretical orientation for the justification of an inquiry. According Robert King Merton (1963) anomic situation will occurs in any society when the political institutions and its representative failed from performing their historical and constitutional responsibility. Merton argued that when state representative that laid down illegitimate means of making ends in the society failed to distribute the resources of the society equally it will foster disorganization. This is because people will design another alternate means of reaching their goals which might negate the generally accepted goals of the society. In Nigeria, the Nigerian government in the 40s, 50s, $60 \mathrm{~s}, 70 \mathrm{~s}$, and $80 \mathrm{~s}$, had a solid plan for the growth and development of educational system in the country. All courses in the citadel of learning are properly empowered, monitored and supported so that the manpower development of the country will result to amelioration in human living conditions. In relation to Nigeria, one of the fundamental problem facing journalism as a profession in Nigeria is rooted back to the inability of the government to allow the media house operate based on the organizational code of conduct and ethics. In Nigeria, large number of the journalists are jailed, kidnap, and currently facing isolation or humiliation in their country of origin because of the fact that they released antisocial reports or actions carried by the state political actors against the growth and development of the country. When large numbers of journalists in the country are faced with unemployment issue, poverty and economic hardship, they will denied all the expected means of achieving success in the community and result to lack of trust, civil unrest ,psychological trauma and other social vices in the country.

Structural Functionalist Theory is adopted because the theory is centered on how social order can be adopted in order to promote social order and social development in the country. The work of Structural functionalism is rooted back to the scholar work of Talcott Parsons in the $19^{\text {th }}$ century in the United States of America. The fundament assumptions of the functionalists is that social order can only be made possible when there are strong value consensus in the relationship that exist between the various parts (institutions) and the entire whole (Society). Parsons avers that the quality of the relationship must be based on functional imperatives and each of the parts must be willing to cope and be willing to work hand in hand for the achievement of amelioration in the living conditions of the populace socially, politically, psychologically and economically. In relation to Nigeria, it obvious that Nigeria is in a stage of anomic conditions that needs proper invention so as to reduce the harms that can be generated from the emerging trends in the failing part of the journalists in Nigeria. The act of fighting against the dissemination of misleading information and correcting the code of ethics of the journalism profession should be done by the collective responsibility of the totality of the entire population in Nigeria. It is proved beyond doubts that problem of one is the problem of all in a value consensus solution, therefore, the negative preconceived societal notions on the role and significance of journalism profession should be totally erased so that semblance of orderliness can be achieved in the area of dissemination needful information in our society for development 


\section{MATERIALS AND METHODS}

Qualitative method of inquiry is adopted for the collection of verbal information from the journalists in different media houses in Lagos, Ogun and Oyo States. More so, verbal information is also collected from the community members through the use of tape for collecting in-depth information from the respondents at various study locations in Nigeria Analytic. research design is adopted in carrying out the inquiry. This is because the little or nothing was empirically known about the profession (journalism) by the researcher on the well beings of the journalists in Nigeria from inception. However, the little time the researcher visited some of the media otganisations in different locations a lot of complains were derived from the journalist concerning safety of the profession and even the community members. Cross sectional survey methods is adopted while the frames are the three major States, communities, media houses, sections and sub-sections selected for the inquiry. Thus, in each of the media houses there are various sections and sub-sections that are considered during the interview because of the professionalism associated with the job. Therefore, Multi-stage sampling technique (Probability) will be adopted for breaking down the study selected locations while snowballing technique (Non-probability sampling technique) is used to select the respondents that are willing to participate in the research inquiry. The sample size used for collecting information from the respondents is estimated to twenty-five (25) journalists that are willing to share their opinion concerning the public perception of the insecurity and safety issues relating to the journalism as a profession in Nigeria While fifteen (15) societal members are accidentally selected to share their knowledge, opinion and perceptions concerning the safety of journalism as a profession in Nigeria. Large numbers of the journalists were acting too professional in giving the needful information. The information gathered from the journalists and the public members are used for transcription of the qualitative inquiry. In addition, when the research inquiry is ongoing all ethical issues were considered so as not to violate the purpose of the research inquiry. Informed concern was really followed because the researcher firstly introduced himself to them as a researcher who is interested in their situation. More so, all the necessary information collected from the participants are treated with utmost confidential while the researcher was also emotionally neutral concerning all the information gathered from the participants on the field Descriptive and Analytic methods were both adopted in forms of simple percentages and frequency distribution to analyse the socio-demographic characteristics of the respondents while transcription of the in-depth information was used for the qualitative data collected on the specific questions from the participants at the communities understudied

\section{Data Analysis and Interpretations Result}

This section is centered on the analysis of various socio-demographics information collected from various participants (Journalists) in the two selected communities. Thus, 25 respondents participated and their socio-demographics characteristics were explains as follows

\begin{tabular}{|c|c|c|c|c|}
\hline \multicolumn{5}{|c|}{ Socio-demographics Characteristics of the Participants on the Field } \\
\hline 1) & $\mathrm{Ag}$ & of the respondents & Frequency & Percentages \\
\hline & a) & Less than 20 years & - & $\%-$ \\
\hline & b) & $21 \mathrm{yrs}-25$ years & 7 & 28.0 \\
\hline & c) & $26 y r s-30$ years & 5 & 20.0 \\
\hline & d) & 31 yrs-35 years & 2 & 8.0 \\
\hline & e) & $36 y r s-40$ years & 7 & 28.0 \\
\hline & f) & $41 \mathrm{yrs}-45$ years & 4 & 16.0 \\
\hline & g) & $46 y r s-50$ years & - & $\%-$ \\
\hline & h) & 51years and above & - & $\%$ \\
\hline
\end{tabular}




\begin{tabular}{|c|c|c|c|}
\hline Total & & 25 & 100.0 \\
\hline 2) & Sex of the Respondents & Frequency & Percentage \\
\hline & a) Male & 18 & 72.0 \\
\hline & b) Female & 7 & 28.0 \\
\hline Total & & 25 & 100.0 \\
\hline 3) & Religious Affiliation of the Resp & pondents & Percentage \\
\hline & a) Christians & 12 & 48.0 \\
\hline & b) Muslims & 8 & 32.0 \\
\hline & c) Traditional Worshipper & 4 & 16.0 \\
\hline & d) Others Specify & 1 & 4.0 \\
\hline Total & & 25 & 100.0 \\
\hline 4) & Level of Education Qualification & n Frequency & Percentages \\
\hline & a) No formal Education & - & $-\%$ \\
\hline & b) Vocational skill & - & $-\%$ \\
\hline & c) Primary education & - & $-\%$ \\
\hline & d) Junior Secondary School Ed & ducation - & $-\%$ \\
\hline & e) Senior Secondary School edv & ducation - & $-\%$ \\
\hline & f) $\mathrm{ND} / \mathrm{HND} /$ University Educat & tion 10 & 40.0 \\
\hline & g) Professional qualification & 12 & 48.0 \\
\hline & h) Others Specify & 3 & 12.0 \\
\hline Total & & 25 & 100.0 \\
\hline 5) & Marital Status & Frequency & Percentages \\
\hline & a) Married & 15 & 60.0 \\
\hline & b) Singled & 4 & 16.0 \\
\hline & c) Widowed & 5 & 20.0 \\
\hline & d) Divorced & 1 & 4.0 \\
\hline & e) Separated & - & $\%-$ \\
\hline & f) Others Specify & - & $\%-$ \\
\hline Total & & 25 & 100.0 \\
\hline 6$)$ & Names of the Organizations & Frequency & Percentages \\
\hline & a) Daily Trust & 3 & 12.0 \\
\hline & b) The Punch Newspaper & 4 & 16.0 \\
\hline & c) The Vanguard Newspaper & 2 & 8.0 \\
\hline & d) Tribune Newspaper & 2 & 8.0 \\
\hline & e) Fresh F.M & 3 & 12.0 \\
\hline & f) Paramount F.M & 3 & 12.0 \\
\hline & g) Raypower F.M & 2 & 8.0 \\
\hline & h) OGTV & 4 & 16.0 \\
\hline & i) LSTV & 2 & 8.0 \\
\hline Total & & 25 & 100.0 \\
\hline 7) & Names of States for the research & A Frequency & Percentages \\
\hline & a) Lagos & 8 & 32.0 \\
\hline & b) Ogun & 10 & 40.0 \\
\hline & c) Oyo & 7 & 28.0 \\
\hline Total & & 25 & 100.0 \\
\hline 8) & Occupation Cadre & Frequency & Percentages \\
\hline & a) Senior Staff & 7 & 28.0 \\
\hline & b) Junior Staff & 14 & 56.0 \\
\hline & c) Contract Staff & - & $-\%$ \\
\hline & d) Janitors & - & $-\%$ \\
\hline & e) Others Specify & 4 & 16.0 \\
\hline Total & & 25 & 100.0 \\
\hline 9) & $\begin{array}{l}\text { Nationality } \\
\text { a) The same locality }\end{array}$ & $\begin{array}{l}\text { Frequency } \\
20\end{array}$ & $\begin{array}{c}\text { Percentages } \\
80.0\end{array}$ \\
\hline
\end{tabular}




\begin{tabular}{|c|c|c|}
\hline b) Out of the locality & 5 & 20.0 \\
\hline Total & 25 & 100.0 \\
\hline
\end{tabular}

Source Field work Reports June, 2018

\section{Socio-demographic Characteristics of the Participants}

The socio-demographic characteristic of the twenty-five respondents (Journalists) that participated in the qualitative inquiry were collected through the use of Dictaphone with unstructured questions that guides the researcher on the field. Thus, most of the participants interviewed are not ready to really divulged vital information because of fear of unknown, despite all ethical conditions or constraint that are duly followed. Large numbers of journalists interviewed from different media organizations are not happy about the situation. But data collected from the public members concerning the topic of interest shows that the public members are not really relying on the unguided stories or news gathered by the journalists In addition,. Twenty five (25) journalists are interviewed in different States through the use of snowballing sampling technique while accidental sampling technique was adopted in collecting data from ten (10) public members on the field before transcribing the results

On this ground, the following socio-demographic statistics was derived from the journalists. On the age distribution of the journalists interviewed 7(28.0\%) of them are equally recorded under the ages of 21years-25years and 36years-40years, 5(20.0\%) of the journalists are between 26years-3years, $4(16.0 \%)$ of the journalists were between the ages of 41 years-45years, $2(8.0 \%)$ of them were recorded under the ages of 31 years-35years while nothing was recorded under the ages of Less than 20years, 46years-50years and 51years and above. Result gathered on the sex distribution of the participants shows that $18(72.0 \%)$ of the participants from the selected media organizations were male respondent while $7(38.0 \%)$ of the participants were female counterparts. In addition, result on religion affiliation shows that $12(48.0 \%)$ of the journalists are Christians, 8(32.0\%) of them are Muslims, 4(16.0\%) of them claimed to be a traditional worshipper while $1(4.0 \%)$ of the result was recorded under others specify category (Buddhism) The result gathered on the level of educational attainment of the journalists deciphers that $12(48.0 \%)$ of the participants have professional qualification as a journalists, 10(40.0\%) of them have ND/HND/University First Degree qualification, $3(12.0 \%)$ of the result was recorded in others specify category while nothing was recorded under no formal type of education, vocational skills, Primary school certification, Junior Secondary School qualification, and Senior Secondary School qualifications respectively. The result on marital status indicates that $15(60.0 \%)$ of the participants are married as at the point of conducting the inquiry, $5(20.0 \%)$ of them are widowed, $4(16.0 \%)$ were singled $1(4.0 \%)$ of them claimed to be Divorced as at the time the research was conducted while nothing was equally recorded under Separated and others specify categories respectively. The findings shows that large number of people that participated in the selected media organisations are married men and women In addition, the result gathered on the names of organisations selected for the research inquiry indicates that $4(16.0 \%)$ of the journalists interviewed are equally recorded as The Punch Newspaper and Ogun State Television Stations, 3(12.0\%) of the media houses adopted are The Daily Trust, Fresh F.M AND Paramount F.M respectively while 2(8.0) of the selected locations are recorded under The Vanguard Newspaper, Tribune Newspaper, Ray-power F.M and Lagos State Television respectively. The result gathered on the location distributions of the media houses or organization selected. The result deciphers that $10(40.0 \%)$ of the data collected from the media organisations is from Ogun State, 8(32.0\%) of the data were collected from Lagos State media organisations while $7(28.0 \%)$ of the result of the media houses is from Oyo State, Nigeria. The occupational cadre of the respondents were asked in the questions 
and the result shows that $14(56.0 \%)$ of the participants were Junior Staff, 7(28.0\%) of the journalists that participated in the research inquiry were Senior Staff in the media organisations, $4(16.0 \%)$ of them were recorded under others specify category while nothing is recorded under Casual or contract Staff in the organization. Finally, the result gathered on nationality status of the respondents indicated that $16(72.7 \%)$ of the respondent that participated in the inquiry were Nigerians while 6(27.3\%) of them are foreigners that reside in the communities due to the employment opportunities open to them. The result gathered from the area of nationality shows that over $80 \% \%$ of the participants in all the selected media organisations are Nigerian while $30 \%$ of the interviewed journalists are foreigners at the end of the data collected and transcribed.

The second section of the qualitative analysis is central on the transcription of raw data collected from the Journalists and the public members in various media organisation from different States in Nigeria through the use of tape recorder. Thus, the questions designed and asked from the participants is derived from the research questions in the following context

The first question was asked from the journalists and the public members on what are the predisposing factors that led to insecurity in Journalism as a profession. The result gathered from the two different unit of analysis indicated different opinion, perception and knowledge. The professional ideology shared by the Journalists is quit different from the contribution of the public members concerning the questions asked from them

Question 1. What are the predisposing factors that led to insecurity in the Journalism as a profession in Nigeria?

\section{Respondent One}

In Nigeria, every profession has its own good and bad period which simply means that insecurity is applicable to all profession. Journalism as a profession is not respected in Nigeria until just of recent that people even the Nigerian States political actors just decided to allow the freedom of information bills in the country. The major constraints or challenges of the profession (Journalism) is anchored on wrong political ideology, philosophy and bad governance in Nigeria. It is the Nigerian Government that usually stands as threat towards the growth and development of the media houses in Nigeria especially the Military Era.

\section{IDI/Journalist/Punch Newspaper/ Junior Staff/Lagos/29yrs// 10 ${ }^{\text {nd }}$ February, 2019}

\section{Respondent Two}

The profession is not really respected in this part of the country which to me is a big time disgrace on the professionals handling the profession. It is true that we have brilliant body handling the well being of the institution but why is the profession handled in such way that gives room to local and international debate. It was is said that the profession will be divided along several places as time goes on. Then what are they (Nigerian Institute of Journalists) expecting to the people that undergo mass communication as a course in the Nigerian Universities. The old problem affecting the media organization is the wrong invention or harsh policy enacted by the Nigerian Government but in recent time the problem is within the professional umbrella that can at any time come up with any growth and developmental policies without having deep look into the consequences of the innovationwithout having deep look into the consequences of the innovation

\section{IDI/Journalist/OGTV Station /32yrs/Junior Staff/Ogun State/ /14 ${ }^{\text {th }}$ February, 2019.}

Respondent Three

There are several constraint factors that negate the growth and development of Journalism as a profession in Nigeria. The factors are uncountable in Nigeria. Large numbers of the 
problem affecting the profession is coming from the concept of vested interest from the State Government at all levels, Professional Association of the School of journalism and the entire societal members. The challenges facing the media organisations in Nigeria can only be solved through collective of the generality of the people To be honest with you the radio station are really dealt with in this country because any misused power from the political actors will lead to the close down of the organization in Nigeria. For example the crisis the Fresh F.M faces in Ibadan nearly affect the operation of the otganisation if not for God intervention

\section{IDI/Journalist/Fresh F.M/36yrs/Senior Staff/Oyo State /22 ${ }^{\text {nd }}$ March 2019.}

The outcome of the result gathered from the raw data collected from the journalists in their various organisations and locations deciphers that over $90 \%$ of the journalists believed that there are several factors that can be held responsible as threat towards the growth and development of journalism in Nigeria. Thus, some of the constraint factors that increases level of insecurity in the profession were bad leadership and governance, ill policies adopted, poor performance of the professional bodies governing the organization etc. On the part of the citizens questions asked on what are the predisposing factors that led to insecurity in the Journalism as a profession in Nigeria?

More so, the same question asked from the journalists in different locations and media houses were also asked from public members and their responses were transcribed as follows

Respondent Four

The media organization in Nigeria need to be screened, checkmated and re-orientated because they have deviated from their primary roles. There are always interested in money making. They do not value the ethics of the profession. They are ready to destroy people's image due to the fact that they have been paid. For example a lot of innocent cases such as Senator Bukola Saraki's cases of robbery. The man image was dented and disgrace all over the places. The media organization did not filter out the information to save the lives of innocent people. I think to the best of my understanding the media organization in Nigeria are not working as four realm of the Estates, therefore they are the people creating and expanding the act of insecurity in the country. They needs to be retrain in order to meet up with the standards, ethics and morality expected from their profession

\section{IDI/man/Yoruba/41yrs/Muslim/Iwo Road/ Oyo State/22 ${ }^{\text {nd }}$ March, 2019.}

Respondents Five

In Nigeria who can we trust, who can we help, which of the Newspapers, Radio Stations and Television Station can we trust when it come to dissemination of needful information. None can be trust unless channels Television Station. If I want to listen to needful needs I will just turn to Channels Television Station because that is the only Station in Nigeria where you can listen to genuine information that can be of help to the populace apart from that all other media houses are either supporting the Government or the owners of the media organisation. To me I think the human attitude and behaviour of the journalists in most of the media organisations is the major causes of the threat facing the organisation presently in Nigeria.

\section{IDI/man/Igbo/26yrs/Christian/Anthony Village/ Lagos State/26 ${ }^{\text {th }}$ March, 2019.}

\section{Respondents Six}

The media organisation in Nigeria from the inception have proved to be a failure to the larger society because they are used by the Nigerian political leaders to suppress the citizens they are expected to work with in term of replacing social order in the country. 
Don't mind they their problem comes from the nature of the establishment of the organisation

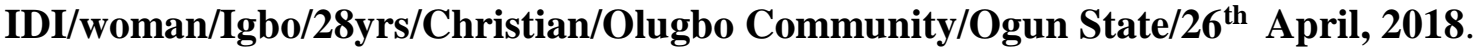

The outcome of the research inquiry indicates that the opinion perception and knowledge of the community members differs from the Journalists. Thus, in the question asked from the two parts most of the factors that lead to insecurity in the profession of journalisms in Nigeria are rooted to subjective interpretation. On the part of the Journalist large number of them close to $98 \%$ of them believed that the factors that led to insecurity in the profession of journalism in Nigeria is due to factors such as ill policies adopted that are not really working for the progress of the profession, bad leadership and governance and act of vested interest demonstrated by the owner of the media houses. But result gathered from the part of the public members was really against what the journalists claimed. The public members from different States were of the view that attitude, behaviour and knowledge depicted by the Journalists in their field was the reason behind what they are facing in the organisations. The journalists are nor working for the interest of the people but the government. So whatever, they are facing today will be as a result of what they have planted

Question 2. The Second question in the research inquiry was structured and directed to public members in order to captured their opinion, perception and knowledge concerning the societal interpretations of the profession (Journalism) in Nigeria are

Respondent One

Media organisations in Nigeria cannot be totally relegated to the background because they still perform some role that are positive despite that large numbers of the organisations have deviated from what they are meant to do as the fourth realm of the Estate. No matter what they have done we cannot totally erased them because without them information in the country will remain stagnate. But I have to say the truth, the media organisation are not worthy to be trusted in any information because they don't filter the information they passed out. But some of them did while others are just sleeping and making money

\section{IDI/man/Yoruba/41yrs/Muslim/Iwo Road/ Oyo State/22 ${ }^{\text {nd }}$ March, 2019.}

Respondents Two

Are you interested in the Nigerian Newspapers, Television or Radio Stations? I don't even watch it at home I better watch cable channels not Nigeria. What would they offer me as a citizens of Nigeria apart from lieing openly or cooking figures. The country is in mess, it will take the special grace of God to restructure the situation and condition of the country back to whay it use to be

\section{IDI/man/Igbo/26yrs/Christian/Anthony Village/ Lagos State/26 ${ }^{\text {th }}$ March, 2019.}

Respondents Three

The problem of what is obtainable or the level of insecurity in the country had gathered it momentum since when we all got it wrong. The purpose of setting most of the media otganisation up from the colonial period is more of ethnic sentiment, religious sentiment and vested interest in the area of money making. All these problem from that period was transported to what we are having as problem in Nigeria as at now. The

\section{IDI/woman/Igbo/28yrs/Christian/Olugbo Community/Ogun State/26 ${ }^{\text {th }}$ April, 2018.}

The result gathered from the public members concerning the topic of interest indicated that large numbers of the societal members are not really interpreting the significant and role of the Journalists in Nigeria positively. The participant interviewed in different States (Ogun, 
Lahos and Oyo States) show their serious level of discomfort concerning the ways and the manners at which the Journalists and lawyers in Nigeria have eroded the moral and constitutional ethics or code of conduct of the otganisation (Media Organisations) in Nigeria. This situation have shown that a lot need to be done by the professional bodies, government at all levels and Nigerians in trying to maintain the semblance of the orderliness we have been clamouring for in the country. The role and significant of the Journalists in Nigeria needs to be screen, evaluated and properly monitor so as to create an enabling environment for all. In the research inquiry 10 public members were interviewed in order to capture their perception, opinion and knowledge based question from the public members. But the outcome indicated that over $80 \%$ of the public members are not really happy with what is obtainable in the media organisations in Nigeria.

Question 3. The third question is centered and directed to the Journalists in order to captured their mind on the types of strategic security measures put in place by the State security apparatus to secure the profession (Journalism) in Nigeria?

\section{Respondent One}

In Nigeria, there are a lot of strategic policies enacted by the professional bodies governing the profession because a lot of independent marketers are are into Journalist which widen the scope of the organisation. Even at the University levels the discipline known as mass communication will be divided at University levels to different area of mass communication such as Pragmatic, Advertisement, Publishing, News casting and reports among others. These shows how the profession bodies are really working to improve the slot of the discipline so as to fast track the development of the organisation. This is done with the help of the Educational boards curriculum committees in Nigeria

\section{IDI/Journalist/Punch Newspaper/ Junior Staff/Lagos/29yrs// 10 ${ }^{\text {nd }}$ February, 2019}

\section{Respondent Two}

Journalists' are professionals in their various field. But in recent time a lot of unexpected is observed in the discipline which needs proper intervention of the States representatives at all levels, the professional organisations connected and the entire citizens in Nigeria. This is because problem of one is problem of all. The professional bodies in Nigeria established by law to regulate the ethics and code of conduct of the media organisations in Nigeria are really trying to bring about the best in the industry through implementations of different policies such as (a) enacting independent Journalist organisation (b) division of mass communication from the university levels to different areas of specializations. All theseshows that they bodies are set to put strategic solutions to the problems that might emanated from the media organisations in Nigeria.

\section{IDI/Journalist/OGTV Station /32yrs/Junior Staff/Ogun State/ $/ 14^{\text {th }}$ February, 2019.}

Respondent Three

A lot of strategies that can improve the media organisation in the time past and recently are adopted to further bring about improve in the services rendered by the Journalist in Nigeria. But despite the plan to improve the services of the journalist, the period of military era mostly violate all the plans or strategic plans put in place to restructure the growth and development of the organisations in Nigeria.

\section{IDI/Journalist/Fresh F.M/36yrs/Senior Staff/Oyo State /22 ${ }^{\text {nd }}$ March 2019.}

The outcome of the inquiry shows that the professional bodies established by the states laws are really working towards achieving growth and development of the profession in Nigeria. But the fact still remains that the role and significance of the media organisations in Nigeria is not felt by millions of Nigeria. The situation of insecurity in the profession of mass 
communication came to been because of lack of transparency and accountability in the mode of operation of the media houses and the journalists in all the media houses in Nigeria. In Nigeria, there are others functions or constitutional responsibility expected from the government at all levels to be done as part of actualizing the dream of the nation towards development orientations. In the other hands the journalists are expected to carry out their primary duties as documented in the constitutions

Question 4. The fourth question was directed to both the journalists and the public members and the responses to the question on whether there is hope for the survival of the profession. The responses gathered are transcribed as follows

\section{Respondent One}

In any countries in the world, we cannot condemn the role and function played or carried out by the journalist because of their dissemination role. The Journalist can only get better and readjust rather thinking that the profession will not be recognized. It can only happen in another planet but in the recent world of ours it is highly impossible to eradicate or stop the role of the journalists in any human existing societies. Therefore, the role might be faultyas at present but I promise you it will be better. The professional bodies established by laws are not sleeping even the federal, states and local government representatives are not sleeping they are all working hard to improve the role of the journalist in Nigeria More so, the security part of the job as well should not be left alone to be carried out by the government alone it is all our responsibility

\section{IDI/Journalist/Punch Newspaper/ Junior Staff/Lagos/29yrs// 10 ${ }^{\text {nd }}$ February, 2019}

\section{Respondent Two}

The profession iwill always survival no matter what the experts in the profession must have been going through. Take for example do you or can you count the numbers of times that the punch newspaper organisation and other radio or television stations were closed because of information divulged which led to the closure of the organisation but today the mentioned organisations were currently working and performing well even those that closed most of the mentioned media organisation are retired from active work but the organisations were still operating

\section{IDI/Journalist/OGTV Station /32yrs/Junior Staff/Ogun State/ /14 ${ }^{\text {th }}$ February, 2019.}

Respondent Three

The Nigerian media houses have been surviving and will still continue to survive because no any other institutions will perform its constitutional responsibility as an institution established by laws of the Federation of Nigeria. I am sure that despite the hazard faced by the journalists locally and internationally, they cannot relegate the role and significance of the Journalists in the dissemination of vital information to the public members. The idea of agitating for eradication of the profession must be totally erased.

\section{IDI/Journalist/Fresh F.M/36yrs/Senior Staff/Oyo State /22 ${ }^{\text {nd }}$ March 2019.}

In addition, the same question asked from the journalist on their opinion, perception and knowledge on whether there is hope for the survival of the profession. The responses gathered from the public members negate the idea, opinion, perception and knowledge of the journalists. But the responses of the public members on the question asked were interpreted and transcribed as follows

Respondent one

If you are opportune to see or meet a common man on the streets or an average Nigerians concerning this topic you will hear and listen to negative contribution. But my stand 
remains my idea and nobody can challenge me or change me if I don't want to change. To be honest the Nigerian governments in all areas of life have failed. We are here talking about the safety of the Journalists what about the safety of a common man on the street. We have not really understand what is expected of the leaders and the followers in the country. A lot of our leaders in Nigeria need to attend security summits and compared what is going on over there with what we have in Nigeria, maybe they can easily discover the missing links or gaps that they need to fulfill

\section{IDI/man/Yoruba/41yrs/Muslim/Iwo Road/ Oyo State/22 ${ }^{\text {nd }}$ March, 2019.}

\section{Respondent Two}

Most of the problem we have in Nigeria is caused by the leaders but the journalist misled Nigerians on several occasions. For example they will not get to the root of the matter and the next thing is for them to released information that is not normal. This will lead to further degeneration of social vices and cause more havoc in the society. I think this is one of the reasons for the constant problems faced by the journalist in Nigeria

\section{IDI/man/Igbo/26yrs/Christian/Anthony Village/ Lagos State/26 ${ }^{\text {th }}$ March, 2019.}

\section{Respondents three}

The survival of the profession (Journalism) in Nigeria is in the hand of God. Take for example, the introduction or reviewing of the mass communication department in all schools or in Nigerian Universities is of great concerns. To some it is a welcome idea for development but in another way round what will happen to people or students who have studied mass community in the Universities in Nigeria because the new curriculum development want diversification and specialization in the discipline. More so, Independent Journalists are everywhere in Nigeria now. We do not need to be c journalists before we carry out their constitutional responsibility in the era of technological advancement in the world today. To those who do not have inner eyes they can only see now but shortsighted in looking into the consequences associated with the future. The profession needs to be totally regulated and follow the moral ethics and conduct of the organisation

\section{IDI/woman/Igbo/28yrs/Christian/Olugbo Community/Ogun State/26 ${ }^{\text {th }}$ April, 2018.}

\section{DISCUSSION OF FINDINGS AND CONCLUSION}

The discussion of the qualitative findings mostly shed comprehensive and subjective meaning to the outcome of an inquiry. Thus, the unstructured questionnaire designed was use as guides for the researcher so as to reduce error of omission or commission. The analysis of the result is divided along two phases and each of the phases help in the interpretation of the inquiry. On the part of the socio-economic characteristics of the respondents, it was noted that over $90 \%$ of the interviewees that participated in the research work were mature people from the all the media houses and States where the study were carried out. In the media institutions selected, result validates the claims that over $70 \%$ of the participants in the inquiry were male while the ratio of the female participants is very low. The result of the religious affiliation of the participant shows that large numbers of the participant enjoy worshipping God in different dimension which was supported by the Nigeria Government and pronounce Nigeria as a secular State On the educational level result, the findings derived on the questions shows that over $90 \%$ of the journalists interview were professional in their jobs The result of the marital status shows that over $60 \%$ of the interviewees are married as at the time the research was conducted while others are single and widowed. The research inquiry was carried out in different places such as Punch Newspaper, The Vanguard Newspapers, Daily trust, Tribume Newspaper, Fresh F.M, Paramount F.M, Raypower F.M, OGTV and LSTV Stations in Nigeria. Over 50\% of the participants working in different 
media field interviewed are Junior Staff compared with the rate of Senior Staff that participated in the research inquiry. Finally, $80 \%$ of the participants were Nigerians while to $20 \%$ are foreigner in the communities. The Yoruba are accommodation people but most people they accommodate sometime override their personality.

The result of the first specific question intends to demonstrate the predisposing factors that lead to insecurity in the Journalism as a profession in Nigeria. The result shows that over $80 \%$ of the journalists claimed that the predisposed factors that lead to insecurity in journalism as a profession is historical in nature. This statement was validated in the claim of Agbaje (2014) when he argued that evidently, Nigerian Journalism was not guided at inception by any law or regulations. Precisely, there was none in place to define the requirements, composition and operations of the players in the industry. Nigerian Journalism was dominated, at the beginning, by people drawn from several pools. This is one of the major causes mentioned by the Journalists which is in line with what is still obtainable in the country. More so, about $10 \%$ said insecurity is observed in the profession because independent marketers are currently dominating the sphere of communication in Nigeria For example Oso (2012) laments that the liberalization and commercialization policy of the federal government of Nigeria of the 1980s and 1990s threw a lot of challenges to the professional standards of journalism practice in Nigeria. The policy made all forms of news coverage to be evaluated from the commercial point of view. The impact of the policy became noticeable on journalists' sense of news judgment, especially in the broadcast media. News events not sponsored were hardly aired. The result gathered from the public member seems to negate the causes of the problem of insecurity in the profession Journalism( Over $90 \%$ of the public members believed the journalists are not meeting up with the historical responsibility of the states. They are more interested in their personal gain but not promoting the culture of transparency, emotional neutrality and credibility. This is known as the determinant of insecurity in the profession

The conclusion of the second question was derived from the contributions of the respondents or public members on the question that intends to know the societal interpretations of the profession (Journalism) in Nigeria. The conclusion derived shows that over $100 \%$ of the public members interviewed on the societal interpretation of the role and significance of the profession (Journalism) condemned the profession because of several misleading information that are not properly screened, evaluated and filtered before disseminating the information to the outside world. To them such situation will degenerate to crisis of legitimacy rather than creating semblance of orderliness in our country (Nigeria). This statement was validated when Oso (2012) avers the practice of journalism in Nigeria has been characterized by flaws that had prevented it from being referred to as a profession. At inception, the Nigerian media space was occupied by practitioners who neither saw themselves as professionals nor made professionalism their watchword More so, Oso attest:that the Nigerian Journalists are not allow to enjoy autonomy and detach required for the practice of his trade. This has led to the sale of news which is killing professionalism in Nigerian Broadcast journalism. The third conclusion was drawn from the question that intend to discover forms of strategic security measures put in place by the State security apparatus to secure of the profession. The conclusion derived from the question deciphers that over $90 \%$ of the journalist argued that there are several strategic security plans put in place by the Nigerian Government and the Professional bodies established by law to monitor the well being of the institution in Nigeria. According to Adaja (2011) the Nigerian Media can not be fully referred to as a profession. Although, the Nigerian Union of Journalists parades a Code of Conduct in which in its Article I (i) referred to the Union as a professional body as well as a trade union it is instructive to point out that, Journalists (Press) do not 
operate or function in a vacuum; the society ascribes to them certain social responsibilities. The motive for the establishment of the organiation cannot adequately fill the missing gap. Only those who are sufficiently trained and grounded in journalism or mass communication can perform these functions satisfactorily. Thus, journalism, like other disciplines such as law, medicine, engineering, etc could be described as a profession, especially when considering its impacts and role in the society

The last conclusion was drawn from the question that intends to know if there is any form of hope for the survival of the profession. The conclusion was drawn from two different perspectives on the part of the journalist $100 \%$ of them said there is hope for the profession in as much there is hope for Nigeria as a country for survival while the public members claimed that the hope for the function, role and significance of the press is blinking. The hope of the discipline needs to be urgently attended to in order to avoid crisis of legitimacy in the country

\section{RECOMMENDATIONS}

a) The growth and development of Nigeria as a nation depend largely on what the entire citizens can do to save the nations from facing retrogressive development. The Government needs to allow autonomy of the medias houses so that the information gathered will not be used to affect the people they are meant to protect.

b) The principle of meritocracy is missing in the profession. The only way to save the profession is to restore sanity, credibility, transparency and accountability back to the ethics of the media organisations in Nigeria

c) The problem of one is problem of all. In as much the organisation is going through several challenges, the public members should purged themselves out of preconceived notion that information can be collected or journalism do not needs the concept of professionalism. The area should be dealt properly with so that the essence of dissemination of valuable information will be the watch word

d) The Nigerian journalists still need to be train and retrain as the fourth real of the Estate because large number of the public members did not really believed in their role and significance in the area of dissemination of information

e) All immoral acts that will leads to collection of bribe from the political elites to forestall the ideology of the opposition should be eradicated

f) The declaration of assets must be stated and highly followed and respected to the latter if there will be needs for collective responsibility rather than affective neutrality in our nation

\section{REFERENCES}

Adaja, T.A. (2011). The Nigerian Media and the Quest for Probity and Accountability in Governance. A A U: African Studies Review, vol. 10, 183 - 204.

Agbaje, A. (1992). The Nigerian Press, Hegemony and the Social Construction of Legitimacy 1960 - 1983. New York: Edwin Mellen.

Black, J. And Roberts, C. (2011), "Doing ethics in media: theories and practical applications" New York: Routledge.

Brown, F. (2011) "Journalism Ethics: A casebook of professional conduct for new media 4th edition" US: Marion street press.

Chibita, M. B. (2010). Developing Relevant Journalism Curricula in Changing Times Experiences from East Africa. A paper delivered at the World, Journalism Education Congress (WJEC), Grahamstown, July 5-7. 
Dare, s. (2011). The rise of citizen journalism in Nigeria - the case of Sahara Reporter. http://reutersinstitute.politics.ox.ac.uk/about/article/the-rise-ofcitizen-journalism Innigeria.html.

Frost, C. (2011).” Journalism ethics and regulation" London: Pearson

Maku, L. (2012) "Mandate, vision, achievements and challenges of the federal ministry of information" retrieveD from fmi.gov.ng

Mare, A. (2010) "Business journalism Ethics in Africa: A comparative study of newsrooms in South Africa, Kenya and Zimbabwe" MA Thesis.

Merton, Robert K. (1968) Social Structure and Anomie.. American Sociological Review 3 (5): 672-682.

Ninalowo, A.M.A, Badru F and Akinyemi R (2010) An Interdisciplinary Discourse on the Human Condition. Lagos. University of Lagos Press

Odufwa, F. (2011) "Digital Broadcast migration in West Africa: Nigeria research report" Association for progressive communication and balancing Act.

Oso, L and Pate, U (2011) "Mass media and society in Nigeria" Lagos: Matthouse Press Limited

Oso, L. (2012). News for Sale! The Challenges and Implications of the Commercialization of News in Nigeria. In L. Oso, D. Soola \& U. Pate (Eds.), Media, Governance and Development: Issues and Trends (pp.83-104). KG, Saarbrucken, Germany: LAP LAMBERT Academic.

Oyekani, F.A.D and Soyombo, O (2005), Society and Governance; The Quest for Legitimacy in Nigeria. Lagos. University of Lagos Press

Pate, U. (2013) "ethics and nation building in Nigeria" National Conference and Annual General Meeting of the Nigerian Institute of Public Relations, NIPR, Abuja

Salawu, A. (2011). Citizen journalism off-line: the (Nigerian) punch's model. http://www.ec.ubu.pt/ec/09/2011mai-10.pdf.

Tabuwe, M. E. \& Tangjong, E. (2010). Impact of Journalism Training on Editorials and News Values in Cameroun. A paper presented at the World Journalism Education Congress (WJEC), Grahamstown, July $5-7$.

Thornton, L. (2012) "ethics means acting beyond interest" retrieved 0ctober 23, 2016 from http://leadingincontext.com/tag/ethics-training/

UNDP (2010). A baseline readiness assessment of the Nigerian media as forum for citizen engagement in the 2011 election. http://www.ng.undp.org/dgd/media-report-baselinesurvey-october-2010.pdf

Ward, S. J. (2013) “journalism ethics” Wahl-Jorg_C021.indd 295

World Bank (2012) "Nigeria: country at a glance" retrieved 20th November 2016 from http://www.corporate-nigeria.com/index/country_profile 